\title{
Thymine Incorporation and Metabolism by Various Classes of Thymine-less Bacteria
}

\author{
By A. P. HARRISON, Jun. \\ Biology Division, Oak Ridge National Laboratory and National Cancer Institute- \\ Atomic Energy Commission Co-carcinogenesis Project, Oak Ridge, Tennessee, U.S.A.
}

(Received 30 March 1965)

\begin{abstract}
SUMMARY
Escherichia coli strain $15 \mathrm{~T}^{-}$yielded $10^{9}$ organisms from $1 \mu \mathrm{g}$. thymine and growth was continuous, not diphasic. Aminopterin-selected thymineless bacteria, on the other hand, required 20-25 $\mu \mathrm{g}$. thymine $/ \mathrm{ml}$. to sustain growth, although thymine incorporation was the same as for strain $15 \mathrm{~T}^{-}$, approximately $10^{-9} \mu \mathrm{g}$./bacterium. In dearth of thymine the aminopterinderived auxotrophs underwent thymine-less death (like strain $15 \mathrm{~T}^{-}$), and in $5 \mu \mathrm{g}$. thymine $/ \mathrm{ml}$, after some initial growth, also underwent thymineless death, although thymine uptake and DNA synthesis continued at a low rate. In $20 \mu \mathrm{g}$. thymine $/ \mathrm{ml}$. (and above) growth was diphasic. From these auxotrophs were derived, presumably the result of a second mutation, strains similar to strain $15 \mathrm{~T}^{-}$. These differed from strain $15 \mathrm{~T}^{-}$, however, as follows: they required $2 \mu \mathrm{g}$. thymine $/ \mathrm{ml}$. to initiate growth, they formed less thymidine phosphorylase, and they did not yield a particular class of revertant characteristic of strain $15 \mathrm{~T}^{-}$. The aminopterin-derived auxotrophs were a thousand times more sensitive to inhibition by cytidine and uridine than were their double mutants or strain $15 \mathrm{~T}^{-}$. This was the only trait discovered to correlate with their high thymine requirement. The high thymine requirement appeared not to be due to a permeability defect. Several classes of revertants were obtained from thymine-less bacteria. The majority regained thymidylate synthetase simultaneously with loss of ability to incorporate thymine efficiently. One class from strain $15 \mathrm{~T}^{-}$was unique: it regained thymidylate synthetase without losing thymine incorporation, and represented the one exception to the rule of mutual exclusion between these two traits. The aminopterin-derived auxotrophs were a distinctive, stable, and remarkably uniform class of thymine-less bacteria. They emphasized the uniqueness of strain $15 \mathrm{~T}^{-}$, and illustrated the dual differentiation from a wild type possessed by their double mutants and also by strain $15 \mathrm{~T}^{-}$.
\end{abstract}

\section{INTRODUCTION}

Numerous thymine-less auxotrophs of Aerobacter aerogenes have been isolated by the aminopterin method. All had a high thymine requirement compared with Escherichia coli strain $15 \mathrm{~T}^{-}$. Likewise, aminopterin-selected thymine-less mutants from $E$. coli strain 15, from several $E$. coli $\mathrm{k}-12$ strains, and from other bacteria yielded, without exception, auxotrophs with a high thymine requirement. All of Dr T. Okada's aminopterin-derived isolates (personal communication) required twenty times the concentration of thymine as did strain $15 \mathrm{~T}^{-}$. Moreover, the thymineless Bacillus megaterium isolated by Wachsman, Kemp \& Hogg (1964) had a high thymine requirement. It would thus appear that thymine-less bacteria newly 
isolated by the aminopterin method are different metabolically from $E$. coli $15 \mathrm{~T}^{-}$. On the other hand, some aminopterin-derived mutants of $E$. coli reported in the literature show a low thymine requirement, more nearly that characteristic of strain 15 $\mathrm{T}^{-}$. However, one of these, strain $15 \mathrm{H}^{-} \mathrm{T}^{-}$, was derived by $\mathrm{Dr} \mathrm{T}$. Okada (personal communication) as secondary growth from a high-thymine-requiring auxotroph. In the present study low thymine requirers routinely have been derived from high thymine requirers, presumably as a result of a second mutation. The purpose of the present report is to describe the relationship between various classes of thymineless bacteria, and to compare their thymine uptake and metabolism.

\section{METHODS}

Bacteria. Strains and pertinent information are listed in Table 1. Escherichia coli strains 15 and $15 \mathrm{~T}^{-}$were supplied by $\operatorname{Dr}$ Seymour $\mathrm{S}$. Cohen. The latter organism is a u.v.-induced mutant, and was described by Barner \& Cohen (1954). Two strains

Table 1. Isolation and thymine requirement of bacterial strains

\begin{tabular}{|c|c|c|c|c|c|}
\hline Species & $\begin{array}{l}\text { Strain } \\
\text { designa- } \\
\text { tion }\end{array}$ & Parent & $\begin{array}{l}\text { Method of } \\
\text { isolation }\end{array}$ & $\begin{array}{l}\text { Thymine necessary } \\
\text { to sustain full growth } \\
(\mu \mathrm{g} .)\end{array}$ & $\begin{array}{c}\text { Exogenous thymine } \\
\text { incorporated/cell } \\
(\mu \mathrm{g} .)\end{array}$ \\
\hline Aerobacter & $\mathbf{t}$ & - & - & None (prototroph) & - \\
\hline aerogenes & t23 & $\mathbf{t}$ & Aminopterin & 25 & - \\
\hline \multirow[t]{4}{*}{ NCTC 418} & t28 A & t23 & $\begin{array}{l}\text { Concentration } \\
\text { gradient agar }\end{array}$ & 1 & - \\
\hline & t23B & t23 & $\begin{array}{l}\text { Concentration } \\
\text { gradient agar }\end{array}$ & $\sim 2$ & - \\
\hline & t23-1 & t23 B & $\begin{array}{l}\text { Heavy seeding } \\
\text { on thymine- } \\
\text { less agar }\end{array}$ & $\begin{array}{l}\text { None (prototroph, } \\
\text { revertant) }\end{array}$ & 一 \\
\hline & t23 B -7 & t23 B & $\begin{array}{l}\text { Heavy seeding } \\
\text { on thymine- } \\
\text { less agar }\end{array}$ & 1 & - \\
\hline \multirow[t]{7}{*}{$\begin{array}{l}\text { Escherichia } \\
\text { coli }\end{array}$} & 15 & - & - & None (prototroph) & $\begin{array}{l}0.05 \times 10^{-9} \text { when } \\
\text { grown in } 5 \mu \mathrm{g} \text {. } \\
\text { thymine } / \mathrm{ml} \text {. }\end{array}$ \\
\hline & $15-1$ & 15 & Aminopterin & $\mathbf{2 5}$ & $0.9 \times 10^{-1}$ \\
\hline & 15-1 B & 15-1 & $\begin{array}{l}\text { Concentration } \\
\text { gradient agar }\end{array}$ & $\sim 2$ & $0.9 \times 10^{-9}$ \\
\hline & $15-1-1$ & $15-1$ & $\begin{array}{l}\text { Heavy seeding } \\
\text { on thymine- } \\
\text { less agar }\end{array}$ & $\begin{array}{l}\text { None (prototroph, } \\
\text { revertant) }\end{array}$ & 一 \\
\hline & $15 \mathrm{~T}^{-}$ & 15 & u.v.-induced & 1 & $0.9 \times 10^{-9}$ \\
\hline & $15 T^{--3}$ & $15 T^{-}$ & $\begin{array}{l}\text { Heavy seeding } \\
\text { on thymine- } \\
\text { less agar }\end{array}$ & $\begin{array}{l}\text { None (prototroph, } \\
\text { revertant) }\end{array}$ & $\begin{array}{l}0.9 \times 10^{-9} \text { when } \\
\text { grown in } \\
\text { thymine }\end{array}$ \\
\hline & $15 T^{--6}$ & $15 T^{-}$ & $\begin{array}{l}\text { Heavy seeding } \\
\text { on thymine- } \\
\text { less agar }\end{array}$ & $\begin{array}{l}\text { None (prototroph, } \\
\text { revertant) }\end{array}$ & $\begin{array}{l}0.07 \times 10^{-9} \text { when } \\
\text { grown in } 5 \mu \mathrm{g} . \\
\text { thymine } / \mathrm{ml} \text {. }\end{array}$ \\
\hline
\end{tabular}

are not listed: $E$. coli strain $\mathbf{C T}^{-}$was supplied by Dr R. L. Sinsheimer; it was isolated by Dr P. C. Hanawalt by the aminopterin method following u.v. irradiation; E. coli strain $15 \mathrm{H}^{-\mathrm{T}^{-}}$was received from $\mathrm{Dr} \mathrm{T}$. Okada.

Media. Buffer (pH 7.1) contained $0.6 \%$ (w/v) $\mathrm{Na}_{2} \mathrm{HPO}_{4} .7 \mathrm{H}_{2} \mathrm{O}$ and $0.15 \%$ $\mathrm{NaH}_{2} \mathrm{PO}_{4} \cdot \mathrm{H}_{2} \mathrm{O}$. Liquid minimal medium comprised in addition to buffer $0 \cdot 10 \%$ 
$\mathrm{NH}_{4} \mathrm{Cl}, 0.05 \% \mathrm{KCl}, 0.02 \% \mathrm{MgCl}_{2} .5 \mathrm{H}_{2} \mathrm{O}, 0.03 \% \mathrm{Na}_{2} \mathrm{SO}_{4}$, and $0.3 \%$ glucose (yieldlimiting to $4 \times 10^{9}$ cells $/ \mathrm{ml}$.). Glucose, buffer, and the salt mixture (suitably concentrated) were autoclaved separately, were cooled, and were mixed aseptically. Stock cultures were maintained on minimal medium containing $1.6 \%$ agar. For thymine-less bacteria $50 \mu \mathrm{g}$. thymidine $/ \mathrm{ml}$. was included. Minimal agar for plating contained $0.5 \%$ glucose. Sterile buffer was used as diluent. For routine plate counts enriched agar was used. It contained $0.20 \% \mathrm{~K}_{2} \mathbf{H P O}_{4}, \mathbf{0 . 2} \%$ yeast extract (Difco), $\mathbf{0 . 5} \%$ trypticase (Baltimore Biological Laboratory), $\mathbf{0 . 5} \%$ glucose, $50 \mu \mathrm{g}$. thymidine/ml., and $1.6 \%$ agar. The diluent had the same composition but without thymidine and agar.

Isolation of mutants. Thymine-less auxotrophs were acquired by two or more serial passages in liquid minimal medium supplemented with $200 \mu \mathrm{g}$. thymidine/ $\mathrm{ml}$. and $200 \mu \mathrm{g}$. aminopterin/ml. (Okada, Homma \& Sonohara, 1962), followed by replicate plating (Lederberg \& Lederberg, 1952) from enriched agar to minimal agar. Increasing the aminopterin concentration to $500 \mu \mathrm{g} . / \mathrm{ml}$. was necessary in some instances; incorporation of $200 \mu \mathrm{g}$. 5-bromo-deoxyuridine $/ \mathrm{ml}$. had no effect. Thymine-less bacteria obtained in this way required 20-25 $\mu \mathrm{g}$. thymine $/ \mathrm{ml}$. in liquid minimal medium to sustain maximum growth. Strains with a low thymine requirement were isolated from these auxotrophs as follows: $10^{9}$ washed cells in buffer were spread onto minimal agar, a cylinder of agar was cut from the middle of the plate with a cork borer $1 \mathrm{~cm}$. in diameter, and $1 \mathrm{mg}$. thymine in $0 \cdot 1 \mathrm{ml}$. water was placed therein. After 2 days of incubation satellite colonies appeared at the periphery of the confluent growth surrounding the depression. These colonies were streaked on enriched agar to ensure purity, and stock cultures were prepared on minimal agar containing thymine. The low thymine requirers will be referred to as double mutants. They may also be acquired by heavy seeding on minimal agar containing $2 \mu \mathrm{g}$. thymine $/ \mathrm{ml}$.

Chemicals. Leucovorin was a gift from Dr E. H. Dearborn, Lederle Laboratories. Aminopterin, folic acid, 5-bromo-deoxyuridine, the various deoxyribonucleotides, deoxyribonucleosides, and related compounds were purchased from California Corporation for Biochemical Research. Dihydrofolic acid, for use in dihydrofolic reductase assays, was prepared by $\mathrm{Na}_{2} \mathrm{~S}_{2} \mathrm{O}_{4}$ reduction of folic acid as described by Futterman (1957). Tetrahydrofolic acid, for thymidylate synthetase assays, was prepared by catalytic reduction of folic acid as described by Kisliuk (1957). Tritiated thymine and thymidine were purchased from Nuclear-Chicago Corporation.

Growth studies. Bacteria from a refrigerated stock culture were transferred to $5 \mathrm{ml}$. liquid minimal medium (supplemented as required) and incubated overnight without forced aeration. This fresh culture (washed twice with $20 \mathrm{ml}$. buffer at the centrifuge) served as inoculum for $10 \mathrm{ml}$. liquid medium in nephelometer (Coleman Model 9 Nepho-colorimeter) cuvettes with glass tubes through aluminium caps to permit gentle aeration with a Marco air pump. The cultures were incubated at $38^{\circ}$ in a constant-temperature water bath. Growth was monitored by the following means : nephelometrically (against Coleman Nephelos standards) to measure mass, microscopically (Petroff-Hauser counting chamber) to assay for total organisms, and by means of plating (spreading method) to assay for viable organisms. Enriched agar served for routine plating. Where larger culture volumes were required, as in DNA assays, cultivation was in $130 \mathrm{ml}$. medium within gas-washing bottles and 
aeration through the spargers was provided by compressed air. DNA assays were done on trichloroacetic acid extracts by the Burton (1956) modification of the Dische reaction.

Thymine incorporation. Minimal medium in the cuvettes was supplemented with tritiated thymine. After various periods of incubation $0.1 \mathrm{ml}$. samples were transferred to $0.9 \mathrm{ml}$. of $1 \%$ aqueous formalin. Samples from cultures of high cell density were further diluted with formalin to maintain a cell concentration of $10^{7} / \mathrm{ml}$. Micropipettes were used to spread $0.05 \mathrm{ml}$. evenly onto degreased stainlesssteel planchets. Thus the number of organisms on the planchets was held to approximately $10^{6}$, and decrease in radioactivity due to self-absorption (by exponentially growing cells) was held to $\mathbf{2 5} \%$. The planchets were dried under an infrared lamp, exposed for $20 \mathrm{~min}$. to fixative $(95 \%$ ethanol + glacial acetic acid, 3+1; van Tubergen \& Setlow, 1961), passed through a series of ethanol solutions of decreasing concentration (from 95 to $25 \%$ ), and finally passed through two changes of water. In this procedure the cells (containing incorporated tritiated thymine) adhered to the planchets, whilst residual tritiated thymine was removed. The radioactivity was measured with a Packard gas-flow proportional counter. From the specific radioactivity of the thymine the amount of thymine incorporation by the organisms was calculated, and is plotted in the figures herein as $\mu$ g. thymine incorporated $/ \mathrm{ml}$. culture.

Enzyme assays. Cell homogenates for dihydrofolic reductase and thymidylate synthetase assays were prepared as follows : $130 \mathrm{ml}$. of exponentially growing culture were harvested when the nephelometric measurement became 1000 (equivalent to $8 \times 10^{8}$ cells $/ \mathrm{ml}$.). The organisms were chilled, washed with cold buffer, suspended in $5 \mathrm{ml}$. of buffer, and homogenized with a French pressure cell (American Instrument Co.). The homogenates were centrifuged to remove particulate matter, and were assayed immediately and after overnight storage at $-\mathbf{2 2}^{\circ}$. The method described by Misra et al. (1961) and Mathews, Scrimgeour \& Huennekins (1963) was employed for the dihydrofolic reductase assays, and the spectrophotometric method described by Friedkin (1963) was used for the thymidylate synthetase assays. Temperature was $23^{\circ}$. From the initial slopes of the absorbance vs. time curves the m $\mu$ moles substrate converted $/ \mathrm{min}$. were calculated. These results were then related to mg. homogenate protein. Homogenate protein was determined by the FolinCiocalteau method as described by Layne (1957).

It was desired to carry out the thymidine phosphorylase assays on organisms grown on thymine $(5 \mu \mathrm{g} . / \mathrm{ml}$.) and on thymidine $(50 \mu \mathrm{g} . / \mathrm{ml}$.). Since the activity of this enzyme decreases greatly during late exponential growth, the cultures were harvested after only three mass doublings, when the nephelometric measurement had become 200 (equivalent to $2 \times 10^{8}$ cells $/ \mathrm{ml}$; $1 \times 10^{8}$ cells $/ \mathrm{ml}$. in the case of strain 15-1). Organisms from $700 \mathrm{ml}$. of culture were washed with cold $0.03 \mathrm{M}$-sodium phosphate buffer ( $\mathrm{pH} 7 \cdot 1$ ), suspended in $5 \mathrm{ml}$. buffer, and homogenized with the French pressure cell. The homogenates were dialysed for 9-12 hr at $5^{\circ}$ against demineralized water flowing at a rate of $1 \mathrm{l} / \mathrm{hr}$, centrifuged to remove particulate matter, and stored at $-22^{\circ}$. The homogenate was assayed as follows: $0.05 \mathrm{ml}$. was added to test tubes held at $0^{\circ}$ and containing $1 \cdot 2 \mu$ mole $(3 \cdot 0 \mu \mathrm{c}$.) tritiated thymidine in $0.65 \mathrm{ml}$. 0.03 M-sodium phosphate buffer $(\mathrm{pH} 7 \cdot 1)$. The tubes were placed simultaneously in a $38^{\circ}$ constant-temperature bath. At various intervals from 0 to $30 \mathrm{~min}$. a tube was removed, the reaction terminated by the addition of $7 \mathrm{ml}$. 
ethanol, and the resulting protein precipitate removed as described by McNutt (1955) for nucleoside transdeoxyribosidase assay. (The control received thymidine after the addition of ethanol.) The preparation was then taken to dryness at $50^{\circ}$ under an air jet. After addition of carrier thymine and thymidine the dried material was chromatographed (descending) on Whatman no. 1 paper with water, requiring 4-5 hr. The u.v.-absorbing thymine and thymidine spots were eluted with $10 \mathrm{ml}$. of water. To detect breakdown of thymidine to thymine, radioactivity was measured on a $0.1 \mathrm{ml}$. sample added to $5 \mathrm{ml}$. of scintillation mixture [175 g. naphthalene, 7 g. 2,5-diphenyloxazole, and $0 \cdot 375$ g. 1,4-bis-2-(4-methyl-5-phenyloxazolyl)benzene in 1 l. 1,4-dioxane] with a Packard liquid-scintillation spectrometer.

The same homogenates were used for nucleoside transdeoxyribosidase assays. Temperature was $38^{\circ}$. The method was that described by McNutt (1955) except that radioactivity rather than microbiological assay was used to measure the quantity of product in the eluted spots. The amount of thymidine formed was measured from water chromatograms as in the thymidine phosphorylase assays, and the fate of the reactants was analysed also from chromatograms developed with water-saturated butanol and with isobutyric acid+water+ammonia (198 ml. isobutyric acid $+100 \mathrm{ml}$. water $+4.5 \mathrm{ml}$. $\mathrm{NH}_{4} \mathrm{OH}$ mixture).

\section{RESULTS}

Growth and thymine incorporation. The thymine deficiency of the aminopterin mutants was alleviated only by thymidylate, thymidine, and thymine. Neither thymidine triphosphate nor any of the other deoxyribonucleotides, deoxyribonucleosides, ribonucleotides, ribonucleosides, or free bases will replace these compounds. Nor will folic acid, leucovorin, riboflavin, $\mathbf{B}_{12}$, or methionine, added singly or in combination.

Figure 1 illustrates the high thymine requirement of a typical aminopterinselected auxotroph. Approximately $25 \mu \mathrm{g}$. thymine $/ \mathrm{ml}$. was necessary to sustain maximum growth, and most of the thymine remained in the culture filtrate. At low thymine concentrations, for instance $5 \mu \mathrm{g}$. $/ \mathrm{ml}$., the culture increased somewhat in cell number, then underwent thymine-less death, and most of the thymine remained in the filtrate. This is in contrast to strain $15 \mathrm{~T}^{-}$which in $1 \mu \mathrm{g}$. thymine/ml. showed a normal growth curve and yielded $10^{\circ} \mathrm{organisms} / \mathrm{ml}$. Aminopterin-derived auxotrophs such as strains t23 and 15-1 rapidly converted thymidine to thymine; diphasic growth by thymidine cultures was a manifestation of growth actually in thymine. Thymidylate was the best source of thymine for the aminopterin-derived auxotrophs; growth was not diphasic, and the cell yield was usually as good as with strain $15 \mathrm{~T}^{-}$.

Figure 2 illustrates thymine-less death and the lack of DNA synthesis by strain 15-1 in the absence of thymine. A. aerogenes strain t23 responded likewise. No thymidylate synthetase was detected with either mutant (Table 2). Moreover, Dr K. G. Lark (personal communication) cultivated both bacteria in $\mathrm{D}_{2} \mathrm{O}$ with thymidylate, then transferred them to $\mathrm{H}_{2} \mathrm{O}$ lacking thymidylate for $1 \mathrm{hr}$, and observed only one band from extracted DNA in the analytical centrifuge. Apparently little if any DNA was synthesized.

Although thymine-less death by strain 15-1 occurred in $5 \mu \mathrm{g}$. thymine/ml., DNA synthesis took place. Observe in Fig. 3 that the rates of DNA synthesis and thymine 
incorporation became identical, but were less than the rate of mass increase; that the initial thymine uptake by strain $15-1$ and $15 \mathrm{~T}^{-}$was the same; and that $15-1$ approximately doubled in cell number before thymine-less death ensued. These observations lead to the idea that the poor growth of strain 15-1 in low thymine was not due to defective permeability. Strain 15-1 responded the same in $5 \mu \mathrm{g}$. thymine/ $\mathrm{ml}$. whether the inoculum was thymine-grown $(\mathbf{3 0} \mu \mathrm{g}$. $/ \mathrm{ml}$.) or thymidylate-grown $\left(6 \mu \mathrm{g} . / \mathrm{ml}\right.$.) Decreasing the temperature from $38^{\circ}$ to $30^{\circ}$ did not improve growth, but

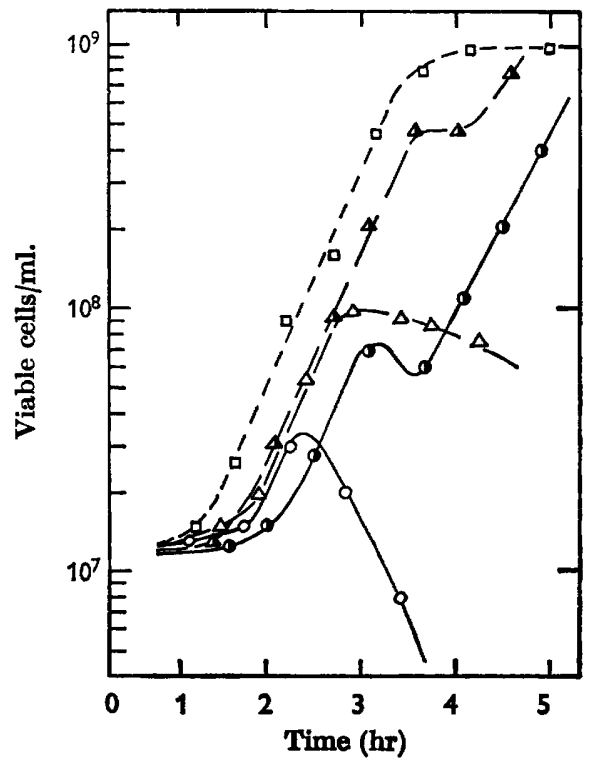

Fig. 1

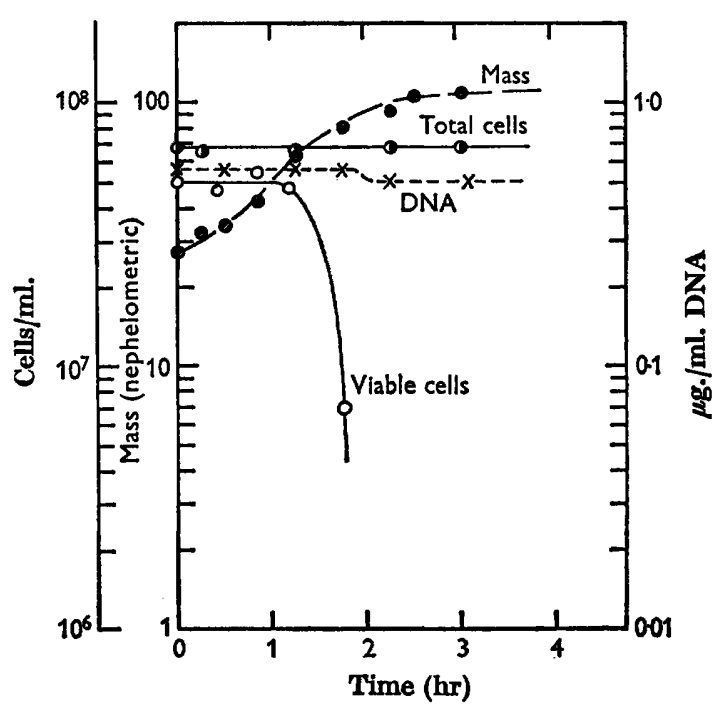

Fig. 2

Fig. 1. Growth of Aerobacter aerogenes strain t23 in liquid minimal medium. $\mathrm{O}-$ $0.04 \mu$ mole (5 $\mu \mathrm{g}$.) thymine $/ \mathrm{ml}$.; $\longrightarrow$, $0.2 \mu$ mole $(25 \mu \mathrm{g}$.) thymine $/ \mathrm{ml}$.; $\triangle \longrightarrow$ $\longrightarrow, 0.04 \mu$ mole $(9.7 \mu \mathrm{g}$.$) thymidine / \mathrm{ml}$; $\Delta-\longrightarrow \longrightarrow, 0.2 \mu$ mole $(48 \mu \mathrm{g}$.$) thymidine/$ ml.; $\square-\longrightarrow \longrightarrow, 0.008 \mu$ mole $(2.7 \mu \mathrm{g}$.) thymidylic acid $/ \mathrm{ml}$.

Fig. 2. Response of Escherichia coli strain 15-1 in liquid minimal medium lacking thymine.

did delay thymine-less death for several hours. The rate of thymine incorporation by strain 15-1 (Fig. 3) was the same as by the parental strain 15 and by revertant strain $15 \mathrm{~T}^{-}-6$. In these three instances the rate of thymine incorporation was much less than the rate of growth. Contrariwise, strains $15 \mathrm{~T}^{-}, 15-1 \mathrm{~B}$, and $15 \mathrm{~T}^{-}-3 \mathrm{in}-$ corporated thymine at a rate equal to the growth rate (Fig. 4).

Figure 5 illustrates the response of strain 15-1 in $30 \mu \mathrm{g}$. thymine $/ \mathrm{ml}$. Note that the thymine uptake plateau preceded a doubled uptake, reflected by diphasic growth and break in DNA synthesis. Strain $15 \mathrm{~T}^{-}$also showed diphasic growth in high thymine concentrations, but to a much smaller degree.

In thymidine the double mutants and strain $15 \mathrm{~T}^{-}$grew equally well. This is in contrast to the poor thymidine incorporation by the parental strains (15-1 and $t$ 23) already cited, and led to an investigation of the enzymes involved in thymidine metabolism.

Thymidine phosphorylase. Strains 15 and $15 \mathrm{~T}^{-}$were cultivated in minimal medium containing $8 \mathrm{~m} \mu \mathrm{moles} / \mathrm{ml}$. $(0.25 \mu \mathrm{c}$. $/ \mathrm{ml}$.) tritiated thymidine at an initial 
cell density of $5 \times 10^{7} / \mathrm{ml}$. After the mass had increased five-fold, requiring $2 \mathrm{hr}$, strain 15 had converted $80 \%$ of the thymidine to thymine and strain $15 \mathrm{~T}^{-}$had converted $85 \%$. Strains $15-1$ and $15 \mathrm{~T}^{-}\left(10^{8}\right.$ organisms $/ \mathrm{ml}$. buffer containing $28 \mathrm{~m} \mu \mathrm{mole} / \mathrm{ml}$. tritiated thymidine) converted $/ \mathrm{ml}$., respectively, $6.2 \mathrm{~m} \mu \mathrm{mole}$ and $5.4 \mathrm{~m} \mu$ mole thymidine to thymine after $5 \mathrm{~min}$, and $19 \mathrm{~m} \mu$ mole and $17 \mathrm{~m} \mu \mathrm{mole}$ thymidine to thymine after $30 \mathrm{~min}$. Although there was apparently no relationship between thymidine phosphorylase activity and thymidine incorporation, the study

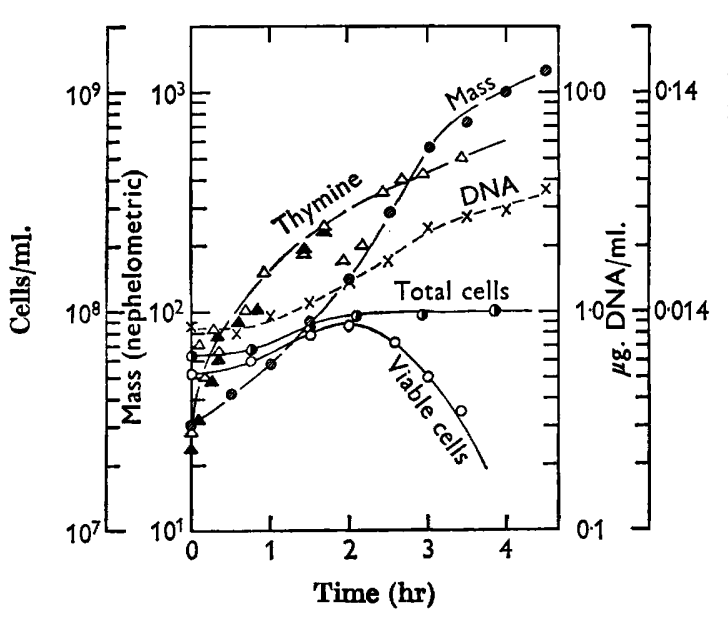

Fig. 3

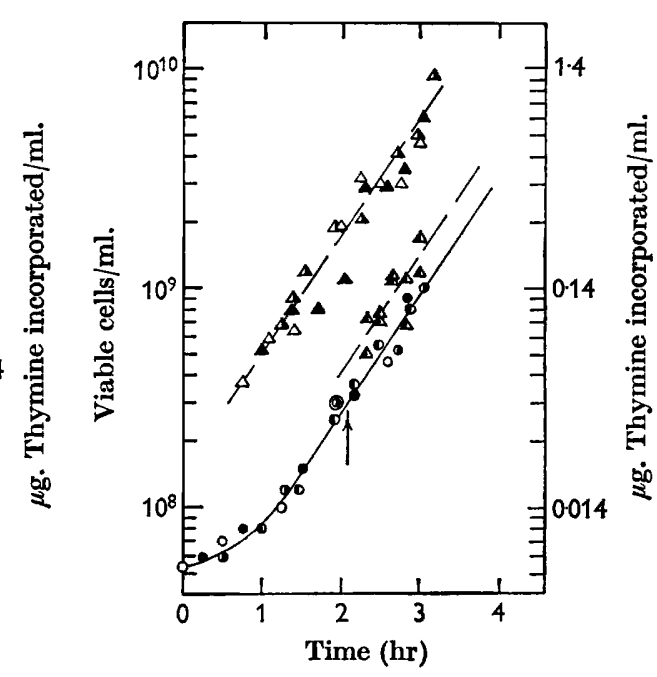

Fig. 4

Fig. 3. Response of Escherichia coli strain 15-1 in liquid minimal medium containing $5 \mu \mathrm{g}$. (4.4 $\mu \mathrm{c}$.) tritiated thymine/ml. $\Delta-\longrightarrow$, thymine incorporation by $E$. coli strain $15 \mathrm{~T}^{-}$under identical conditions giving normal growth.

Fig. 4. Growth and thymine incorporation by various Escherichia coli strains in liquid

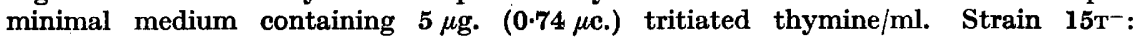
growth; $\triangle$, growth; $\triangle-\longrightarrow$, thymine incorporation. Strain 15 T-3: $\longrightarrow$, $\Delta-\longrightarrow$, thymine incorporation. Strain $15 \mathrm{~T}^{-3}$, but with the thymine added after $2 \mathrm{hr}$ of prototrophic growth (at arrow): $\longrightarrow$, growth; $\triangle \longrightarrow-$ thymine incorporation.

was, nevertheless, extended to include cell homogenates to determine whether enzyme inducibility (reported by Rachmeler, Gerhart \& Rosner, 1961, for prototrophic Escherichia coli) was a property of thymine-less $\boldsymbol{E}$. coli. Table 2 summarizes the results. Thymidine phosphorylase activities of the mutants fell between the extremes established by wild-type strains. Of special interest is the identical thymidine phosphorylase activity of thymine-grown and thymidine-grown strain $15 \mathrm{~T}^{-}$.

The reaction in the reverse direction was weak. Dialysed homogenates from strains $15 \mathrm{~T}^{-}$and $15-1$ were compared $: 0.5 \mathrm{ml}$. was mixed to a volume of $1.2 \mathrm{ml}$. in buffer containing $2 \cdot 4 \mu$ mole $(7 \cdot 4 \mu \mathrm{c}$.) tritiated thymine and $1 \cdot 0 \mu$ mole deoxyribose1-phosphate at $38^{\circ}$ and assayed after 1 and $10 \mathrm{hr}$ incubation. Strains $15 \mathrm{~T}^{-}$and $15-1$ formed, respectively, $0.050 \mu$ mole and $0.040 \mu$ mole thymidine $/ \mathrm{mg}$. homogenate protein after $1 \mathrm{hr}$, and $0.090 \mu$ mole and $0.092 \mu$ mole thymidine $/ \mathrm{mg}$. protein after $10 \mathrm{hr}$. 
Nucleoside transdeoxyribosidase and dihydrofolic reductase. The transdeoxyribosidase assays were carried out as described above except that $0.5 \mu$ mole deoxyriboside replaced the deoxyribose-1-phosphate. Incubation was for $1 \mathrm{hr}$ and, in some experiments, for $6 \mathrm{hr}$. No thymidine was formed with deoxyadenosine, although spots on the chromatograms appeared at the adenine position.

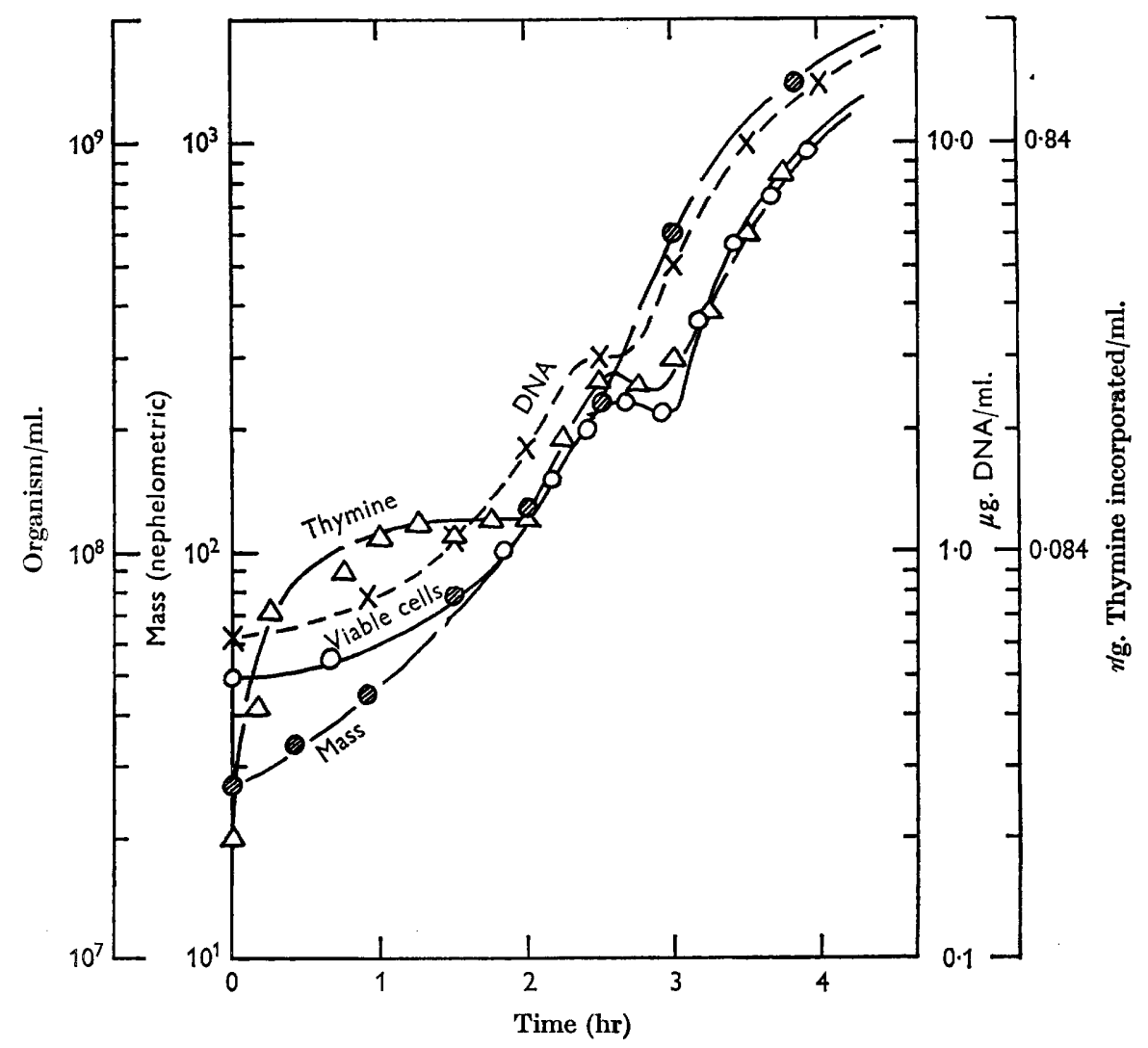

Fig. 5. Response of Escherichia coli strain 15-1 in liquid minimal medium containing $30 \mu \mathrm{g} .(4 \cdot 4 \mu \mathrm{c}$.) tritiated thymine/ml.

Apparently the sugar moiety was removed but not transferred to thymine. Moreover, no measurable thymidine was formed with deoxyguanosine or deoxycytidine. The only measurable thymidine formation was with deoxyuridine; strain $15 \mathrm{~T}^{-}$ formed $0.08 \mu$ mole thymidine and strain 15-1 formed $0 \cdot 10 \mu$ mole thymidine/mg. homogenate protein in $1 \mathrm{hr}$. Thus the difference in thymine incorporation did not reflect a difference in transdeoxyribosidase activity. Further, no correlation between dihydrofolic reductase activity and thymine incorporation was observed (Table 2).

Effect of deoxyribonucleosides and ribonucleosides upon growth. Although deoxyuridine did not replace thymine, it aided in its utilization (Fig. 6). The effect upon diphasic growth was to increase the first growth phase. The effect also occurred on thymidine-grown cultures. Deoxycytidine was the only other deoxyriboside with these properties, but it was less effective (Fig. 6). 
Yeast extract $(0 \cdot 2 \%)$ in plating agars containing thymine gave low yields whilst those agars containing thymidine yielded numbers in agreement with microscopic counts. Plating agars without yeast extract, for example minimal agar, yielded identical numbers whether thymine or thymidine was used, and the numbers

Table 2. Enzyme assays on cell homogenates

\begin{tabular}{|c|c|c|c|c|}
\hline \multirow[b]{2}{*}{$\begin{array}{l}\text { Homogenate } \\
\text { from strain }\end{array}$} & \multirow{2}{*}{$\begin{array}{c}\text { Dihydrofolic } \\
\text { reductase } \\
\text { (m } \mu \text { mole substrate } \\
\text { converted/min./mg. } \\
\text { protein) }\end{array}$} & \multirow{2}{*}{$\begin{array}{c}\text { Thymidylate } \\
\text { synthetase } \\
\text { (m } \mu \text { mole substrate } \\
\text { converted/min./mg. } \\
\text { protein) }\end{array}$} & \multicolumn{2}{|c|}{$\begin{array}{c}\text { Thymidine } \\
\text { phosphorylase } \\
\text { (m } \mu \text { mole thymine } \\
\text { formed/min./mg. } \\
\text { protein) }\end{array}$} \\
\hline & & & $\begin{array}{l}\text { Thymine- } T \\
\text { grown cells }\end{array}$ & $\begin{array}{l}\text { Thymidine- } \\
\text { grown cells }\end{array}$ \\
\hline \multicolumn{5}{|c|}{$\begin{array}{l}\text { Aerobacter aerogenes } \\
\text { NCTC } 418\end{array}$} \\
\hline $\mathbf{t}$ & $4 \cdot 6$ & $\mathbf{0} \cdot \mathbf{2 0}$ & - & - \\
\hline t23 & 4.7 & $\mathbf{0} \cdot \mathbf{0}$ & 一 & - \\
\hline t23A & - & $<0.03$ & - & - \\
\hline t23 B & $4 \cdot 6$ & $\mathbf{0 . 0}$ & - & - \\
\hline t23-1 & - & $\mathbf{0} \cdot \mathbf{2 3}$ & - & - \\
\hline t23B-7 & - & $<0.03$ & - & 一 \\
\hline \multicolumn{5}{|l|}{ Escherichia coli } \\
\hline 15 & $\mathbf{3 \cdot 0}$ & $0 \cdot 37$ & 14 & 120 \\
\hline $15-1$ & $3 \cdot 6$ & $0 \cdot 0$ & 46 & 120 \\
\hline 15-1 B & 一 & $0 \cdot 0$ & 20 & 80 \\
\hline 15-1-1 & 一 & $0 \cdot 35$ & 一 & - \\
\hline $15 T^{-}$ & $3 \cdot 1$ & 0.0 & 65 & 65 \\
\hline $15 T^{-}-3$ & - & 0.10 and $0.04 *$ & - & - \\
\hline $15 T^{-}-6$ & - & $0 \cdot 36$ & 一 & - \\
\hline
\end{tabular}

agreed with the microscopic count. The inhibitors in yeast extract may be certain ribonucleosides. On minimal agar containing thymine, cytidine and uridine decreased the efficiency of plating of strain $\mathrm{t} 23$. The colonies that developed were relatively resistant to inhibition by yeast extract with thymine. (Adenosine and guanosine were less inhibitory than cytidine and uridine.)

Cohen \& Barner $(1956,1957)$ observed that uracil and cytidine inhibited growth of strain $15 \mathrm{~T}^{-}$. Strong inhibition by uridine and cytidine was unique to the aminopterinderived mutants; the low thymine requirers (double mutants) derived from them, like strain $15 \mathrm{~T}^{-}$, were relatively resistant (Table 3). The same response occured, though to a lesser degree, when yeast extract was substituted for uridine or cytidine (Table 3).

Revertants. Heavy seeding of the thymine-less auxotrophs on minimal agar (no thymine) permitted collection of revertants to thymine independence. These were streaked to ensure purity, and stock cultures were prepared on minimal agar. Aerobacter aerogenes strain 123 and Escherichia coli strain 15-1 gave rise to revertants indistinguishable from the respective wild types, growing normally in minimal medium and incorporating thymine poorly. These revertants are represented in Tables 1 and 2 by strains t23-1 and 15-1-1. The $A$. aerogenes double mutant, strain $\mathrm{t} 23 \mathrm{~B}$, gave rise to revertants of two classes. The majority were indistinguishable from a wild type. A few, represented by strain $\mathrm{t} 2 \mathrm{2}_{\mathrm{B}-7} \mathrm{7}$, increased in mass at the usual 
rate in minimal medium, but increased in number very slowly, the number of viable elongated organisms attaining only $10^{8} / \mathrm{ml}$. Growth was normal in $1 \mu \mathrm{g}$. thymine $/ \mathrm{ml}$. Thymidylate synthetase activity was measurable but very low (Table 2).

When inoculated into minimal medium strain t23 $\mathrm{A}$ underwent an immediate increase in mass as the cells elongate. This continued for 3-4 $\mathbf{h r}$ with no loss in viable count, sometimes with a slight increase, and if the medium contained no added thymine a sharp decrease of viability then took place. But if the medium contained $1 \mu \mathrm{g} . / \mathrm{ml}$. thymine, the culture 'recovered' after a slight loss of viability

\section{Table 3. Inhibition of growth in thymine by pyrimidine ribonucleosides and by yeast extract}

\begin{tabular}{|c|c|c|c|}
\hline Strain & $\begin{array}{l}\text { Titre on thymine- } \\
\text { yeast extract } \\
\text { agar/titre on } \\
\text { enriched agar }\end{array}$ & $\begin{array}{l}\text { Titre on thymine- } \\
\text { cytidine-minimal } \\
\text { agar/titre on } \\
\text { enriched agar }\end{array}$ & $\begin{array}{l}\text { Titre on thymine- } \\
\text { uridine-minimal } \\
\text { agar/titre on } \\
\text { enriched agar }\end{array}$ \\
\hline $15 \mathrm{~T}^{-}$ & $1 \times 10^{-2}$ & $3 \times 10^{-1}$ & $5 \times 10^{-1}$ \\
\hline $15-1$ & $3 \times 10^{-5}$ & $1 \times 10^{-4}$ & $4 \times 10^{-5}$ \\
\hline 15-1 B & $1 \times 10^{-4}$ & $4 \times 10^{-1}$ & $2 \times 10^{-1}$ \\
\hline $15 \mathrm{H}^{-} \mathrm{T}^{-}$ & $2 \times 10^{-8}$ & $1 \times 10^{-1}$ & $1 \times 10^{-2}$ \\
\hline $\mathbf{C T}^{-}$ & $8 \times 10^{-1}$ & $8 \times 10^{-1}$ & $4 \times 10^{-1}$ \\
\hline t23 & $7 \times 10^{-4}$ & $4 \times 10^{-5}$ & $1 \times 10^{-5}$ \\
\hline t23 B & $3 \times 10^{-2}$ & $8 \times 10^{-1}$ & $3 \times 10^{-1}$ \\
\hline
\end{tabular}

The composition of enriched agar and minimal agar has been given. Thymine-yeast extract agar is enriched agar in which $25 \mu \mathrm{g}$. thymine $/ \mathrm{ml}$. has substituted for the thymidine. Cell titres on enriched agar and on thymine-minimal agar were identical and agreed with microscopic count. Cytidine and uridine concentrations were $2000 \mu \mathrm{g} . / \mathrm{ml}$. and $200 \mu \mathrm{g} . / \mathrm{ml}$., respectively. Enriched agar plates were incubated overnight, minimal agar plates 3 days.

and normal growth ensued. In $5 \mu \mathrm{g}$. thymine/ml. the $3-4 \mathrm{hr}$ lag did not occur; the culture grew normally from the outset. A very slight thymidylate synthetase activity was detected (Table 2 ). New single-colony isolations from strains t23 A and t23 B-7 yielded cultures with identical traits.

Revertants equivalent to strain t23 B-7 were not isolated from the Escherichia coli double mutant strain 15-1в. All revertants from the latter strain were indistinguishable from the wild type, showing the low rate of thymine incorporation. Strain $15 \mathrm{~T}^{-}$yielded revertants of two classes. The majority, represented by strain $15 \mathrm{~T}^{-}-6$, were indistinguishable from the wild type, possessing the same thymidylate synthetase activity (Table 2), manifesting the same low rate of thymine incorporation, and incorporating approximately the same amount of exogenously supplied thymine/cell (Table 1). A few revertants were unusual; they had attributes in common both with the wild type and with the auxotrophic parent.

Figure 7 shows the growth of revertant strain $15 \mathrm{~T}^{--3}$. In dearth of thymine growth was diphasic, whilst in $1 \mu \mathrm{g}$. thymine/ml. growth was continuous. The culture was pure: (1) re-isolations yielded cultures with identical characteristics, and (2) the culture described in the figure, after overnight incubation, served as inoculum for a new culture which then underwent identical sequential growth. After several months' storage at $5^{\circ}$ this revertant lost its diphasic growth characteristic. Now it grows equally well with or without thymine. When thymine was present, however, it was incorporated at the same rate as by strain $15 \mathrm{~T}^{-}$(Fig. 4). It is as if the normal 
control, which mutually excludes efficient thymine incorporation and high thymidylate synthetase activity, were partially lost, allowing the organisms to adjust freely, in the most economical manner, to either auxotrophic or prototrophic growth.

Crawford (1958) described a revertant $\left(15 \mathrm{~T}^{-} \mathrm{R}\right)$ which incorporated about 30 times

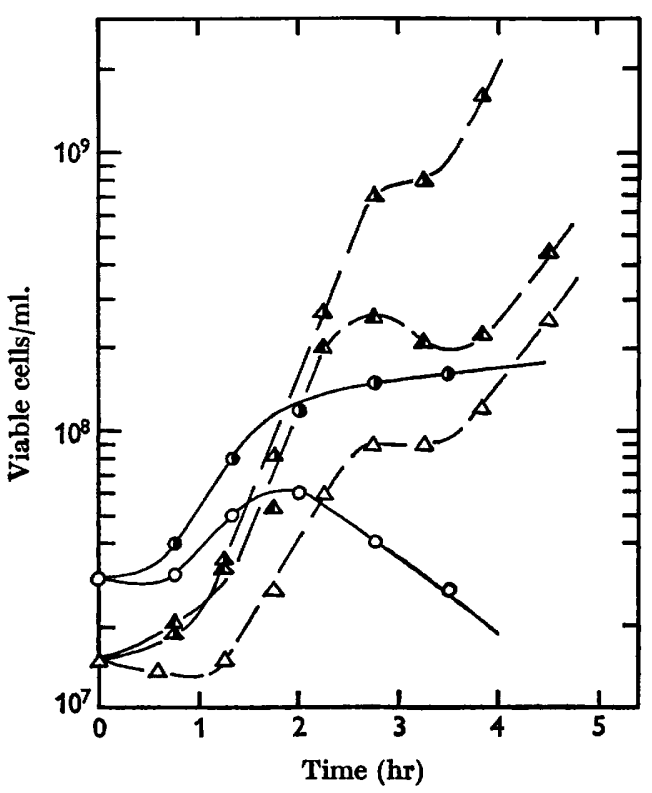

Fig. 6

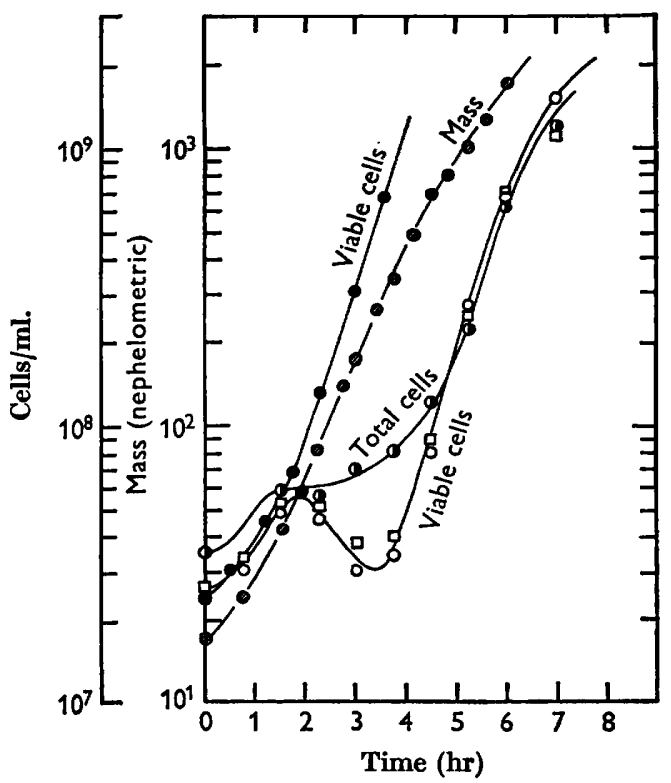

Fig. 7

Fig. 6. Effect of deoxycytidine and deoxyuridine upon growth of thymine-less bacteria in liquid minimal medium. $\bigcirc-$ Escherichia coli strain 15-1 in $5 \mu \mathrm{g}$. thymine/ml. alone; — $-E$. coli strain $15-1$ in $5 \mu \mathrm{g}$. thymine $/ \mathrm{ml}$. plus $50 \mu \mathrm{g}$. deoxyuridine/ml.; $\triangle \longrightarrow$ - Aerobacter aerogenes strain $t 23$ in $25 \mu \mathrm{g}$. thymine/ml. alone; $\Delta \longrightarrow \longrightarrow$, A. aerogenes strain t23 in $25 \mu \mathrm{g}$. thymine $/ \mathrm{ml}$. plus $100 \mu \mathrm{g}$. deoxycytidine/ ml.; $\Delta-$ - $A$. aerogenes strain $\mathrm{t} 23$ in $25 \mu \mathrm{g}$. thymine/ml. plus $100 \mu \mathrm{g}$. deoxyuridine/ml.

Fig. 7. Growth of Escherichia coli strain 15T--3. All curves represent assays in liquid minimal medium lacking thymine except curve where growth was in liquid minimal medium containing $1 \mu \mathrm{g}$. thymine $/ \mathrm{ml}$. All viable counts were determined with the usual thymidine-yeast extract agar except in curve $\square-$ where minimal agar lacking thymine was employed.

the amount of thymine as did a wild-type strain (strain 15) and about one-fourth the amount as the parent (strain $15 \mathrm{~T}^{-}$). He did not assay for thymidylate synthetase or describe growth, but it seems likely that his revertant is of the same class as strain $15 \mathrm{~T}^{-}$-3.

\section{DISCUSSION}

Possession of thymidylate synthetase and ability to incorporate exogenous thymine are independent traits, but tend to be mutually exclusive. Bacteria which possess good thymidylate synthetase activity incorporate thymine poorly. Indeed, various devices have been suggested to enhance thymine or thymidine incorporation by wild-type Escherichia coli (see, for example, Boyce \& Setlow, 1962). Thymine-less 
mutants derived by the aminopterin method (for example, strain 15-1) retain the poor thymine incorporation characteristic of the wild type. However, from them, presumably as the result of a second mutation, strains with more efficient thymine incorporation (for example, strain 15-1 B) may be selected. The most striking feature of the u.v.-derived $15 \mathrm{~T}^{-}$, viewed in relation to the wild type and especially in relation to the aminopterin-derived mutants, is not its lack of thymidylate synthetase, but its exceptionally efficient thymine incorporation. Either $15 \mathrm{~T}^{-}$is a double mutant also, or it arose as the result of a quite different mutational event. Strain $15 \mathrm{~T}^{-}$differs from strain 15-1 B and other double mutants: its growth is sustained in lower concentrations of thymine, its thymidine phosphorylase activity is the same whether it is thymine- or thymidine-grown, and it yields a unique class of revertants. Whilst the usual revertants simultaneously regain thymidylate synthetase activity and lose the ability to incorporate thymine efficiently, some from strain $15 \mathrm{~T}^{-}$regain thymidylate synthetase but still retain the ability to incorporate thymine.

Poor incorporation of thymine does not seem to be caused by defective permeability because growth is initiated at low thymine concentrations. The following facts are pertinent. Growth is improved by deoxycytidine and deoxyuridine (Fig. 6). Growth is inhibited by cytidine and uridine; strains 15-1 and t23, inefficient incorporators of thymine, yield a thousand times fewer colonies in presence of cytidine or uridine than their respective double mutants and other strains which incorporate thymine efficiently (Table 3). Moreover, high concentration of thymine, in its turn, disturbs growth; not only for strain 15-1 (Fig. 5), but also for strain 15 $\mathrm{T}^{-}$, though, significantly, to a lesser degree. It is as if thymine metabolism and pyrimidine ribonucleoside metabolism at some point interfere, and much more so in the aminopterin-derived mutants 15-1 and t23. Poor thymine incorporation by 15-1 can be visualized as due to an endogenous inhibitor, the concentration of which can be increased with exogenous cytidine or uridine and decreased or overcome with the respective exogenous deoxyribonucleosides or with thymine at high concentration. The improved thymine incorporation acquired by mutation of 15-1 to 15-1 B can be visualized in either of two ways: (1) There are two routes to DNA via thymine, one sensitive and the other relatively resistant to the endogenous inhibitor; the mutation represents a switch from the sensitive to the resistant route. (2) There is one route to DNA; the mutation represents a reduction in the ability to accumulate inhibitor.

Breitman \& Bradford (1964) suggested that the more efficient incorporation of thymine by some auxotrophs is due to a greater production of deoxyribonucleosides, allowing deoxyribose transference to thymine "via transdeoxyribosylation and/or coupled deoxynucleoside phosphorylation mechanisms'.

Although revertant strains t23 A and t23 B-7 (Table 2) may be considered 'leaky', there is no evidence for leakiness in the aminopterin-derived auxotrophs 15-1 and t23. Thymidylate synthetase was never encountered. Nor was synthesis of DNA in dearth of thymine detected, either by the Dische reaction (Fig. 2), or by the method using $\mathrm{D}_{2} \mathrm{O}$. Furthermore, these bacteria in dearth of thymine (Fig. 2) responded similarly to $15 \mathrm{~T}^{-}$.

The aminopterin-derived auxotrophs represent a distinctive, stable, and remarkably uniform class of thymine-less bacteria. They emphasize the uniqueness of strain $15 \mathbf{T}^{-}$, and also the dual differentiation from the wild type possessed by their double 
mutants and by strain $15 \mathrm{~T}^{-}$. Further, they illustrate well that thymine-less death may occur in the presence of thymine uptake and DNA synthesis. This latter circumstance may be useful to select between two current representations of thymine-less death: (1) unbalanced growth, proposed by Cohen \& Barner (1954); (2) mistakes in attempted DNA synthesis as proposed by Maaløe \& Hanawalt (1961).

The aminopterin-derived thymine-less bacteria grow very well in thymidylate, a striking difference from their poor growth in thymidine and thymine. The thymidylate is dephosphorylated, probably at the cell surface simultaneously with incorporation of the resulting thymidine. Exogenous thymidine, on the other hand, is rapidly converted to thymine. Apparently the phosphate moiety preserves nucleoside structure. Lichtenstein, Barner \& Cohen (1960) proposed separate routes for the utilization of dephosphorylated nucleotide and exogenous nucleoside. The inefficient conversion of thymidine and thymine to DNA by the aminopterinderived auxotrophs described herein would thus appear to be uniquely associated with the latter route.

The author is indebted to Dr E. Volkin for helpful discussions on pyrimidine metabolism, to Dr W. E. Cohn for advice in paper chromatography, to Dr D. G. Doherty for preparing the tetrahydrofolic acid used in thymidylate synthetase assays, and to Mr L. E. Franklin for skilful assistance early in the work with the many growth studies. The author thanks Professor S. S. Cohen, University of Pennsylvania Medical School, Dr R. B. Setlow, and Dr R. Curtiss for critical readings which led to improvements in the manuscript.

This research was jointly sponsored by the National Institutes of Health, and by the U.S. Atomic Energy Commission under contract with the Union Carbide Corporation.

\section{REFERENCES}

Barner, H. D. \& Cohen, S. S. (1954). The induction of thymine synthesis by T2 infection of a thymine requiring mutant of Escherichia coli. J. Bact. 68, 80.

Boyce, R. P. \& SETLow, R. B. (1962). A simple method of increasing the incorporation of thymidine into the deoxyribonucleic acid of Escherichia coli. Biochim. biophys. Acta, $61,618$.

Breitman, T. R. \& Bradford, R. M. (1964). The induction of thymidine phosphorylase and excretion of deoxyribose during thymine starvation. Biochem. biophys. res. Comm. $17,786$.

Burton, K. (1956). A study of the conditions and mechanism of the diphenylamine reaction for the colorimetric estimation of deoxyribonucleic acid. Biochem. J. 62, 315.

Conen, S. S. \& Barner, H. D. (1954). Studies on unbalanced growth in Escherichia coli. Proc. natn. Acad. Sci., U.S.A. 40, 885.

Conen, S. S. \& Barner, H. D. (1956). Studies on the induction of thymine deficiency and the effects of thymine and thymidine analogs in Escherichia coli. J. Bact. 71, 588.

Cohen, S. S. \& Barner, H. D. (1957). The conversion of 5-methyldeoxycytidine to thymidine in vitro and in vivo. J. biol. Chem. 226, 631 .

Crawford, L. V. (1958). Thymine metabolism in strains of Escherichia coli. Biochim. biophys. Acta, 30, 428 .

Friedkin, M. (1963). Assay of thymidylate synthetase activity. Meth. Enzymol. 6, 124.

Futterman, S. (1957). Enzymatic reduction of folic acid and dihydrofolic acid to tetrahydrofolic acid. J. biol. Chem. 228, 1031.

KisLIUK, R. L. (1957). Studies on the mechanism of formaldehyde incorporation into serine. J. biol. Chem. 227, 805. 
LAYNE, E. (1957). Spectrophotometric and turbidimetric methods for measuring proteins. Meth. Enzymol. 3, 447.

LeDERBERG, J. \& LeDERBerg, E. M. (1952). Replica plating and indirect selection of bacterial mutants. J. Bact. 63, 399.

Lichtenstein, J., Barner, H. D. \& Cohen, S. S. (1960). The metabolism of exogenously supplied nucleotides by Escherichia coli. J. biol. Chem. 235, 457.

MaAløe, O. \& Hanawalt, P. C. (1961). Thymine deficiency and the normal DNA replication cycle. J. mol. Biol. 3, 144.

Mathews, C. K., Scrimgeour, K. G. \& Huennekins, F. M. (1963). Dihydrofolic reductase. Meth. Enzymol. 6, 364.

McNuTr, W. S. (1955). Nucleoside transdeoxyribosidase from bacteria. Meth. Enzymol. 2,464 .

Misra, K., Humphreys, S. R., Friedkin, M., Goldin, A. \& Crawford, E. J. (1961). Increased dihydrofolic reductase activity as a possible basis of drug resistance in leukaemia. Nature, Lond. 189, 39.

OKaDA, T., Homma, J. \& Sonohara, H. (1962). Improved method for obtaining thymineless mutants of Escherichia coli and Salmonella typhimurium. J. Bact. 84, 602.

Rachmeler, M., Gerhart, J. \& Rosner, J. (1961). Limited thymidine uptake in Escherichia coli due to an inducible thymidine phosphorylase. Biochim. biophys. Acta, 49, 222.

van Tubergen, R. P. \& Setlow, R. B. (1961). Quantitative radioautographic studies on exponentially growing cultures of Escherichia coli. Biophys. J. 1, 589.

Wachsman, J. L., Kemp, S. \& HogG, L. (1964). Thymineless death in Bacillus megaterium. J. Bact. 87, 1079. 